\title{
Administration of Water Rights in California
}

Hugh W. Ferrier*

I

HISTORICAL BACKGROUND

It can be safely stated that water is both a necessity of life and the subject of frequent and heated controversy. This is especially true in the State of California. The agricultural economy of California is based upon irrigation, requiring either puniping water from wells or storage, diversion, and transportation of water fron streams to the place of ultimate use. In past years, as the economy expanded, the demands became greater upon the limited supply, and major conflicts between conpeting users developed. As the great metropolitan areas of the state grew and demands for water for doniestic and industrial purposes multiplied, limited local water supplies were exhausted. To meet these growing requirements it became necessary to import water from distant sources. In order to be assured of the water supplies required to satisfy anticipated future needs, cities required rights to develop and utilize water for future use in order to keep in step with the expanding economy. ${ }^{1}$

Meanwhile, the use of water for generation of hydroelectric energy rapidly increased, and power companies and public agencies engaged in generation of hydroelectric energy sought to acquire rights to the use of water to meet these growing needs.

As competing demands met head on, the courts were resorted to. The cases were sometimes mere two-party disputes, and suits involving numerous parties plaintiff or defendant were rare. Controversies were seldom laid to rest by decisions of the courts. Repeated litigation imvolving the same sources of water and some of the samie parties or their successors was commonplace. The rules of law by which the cases were decided were essentially court made, based upon the common law of riparian rights plus the doctrines of appropriation and prescription, "the law of water in the West." The role of the sovereign, the State of California, was essentially a passive one. No agency of the state, representing the public interest, was a party to the litigation or to the processes by which water rights were acquired. That the welfare of the state as a whole was at stake becanie increasingly apparent as time went on.

*Associate Attomey, State Water Rights Board; member, Sacramento Bar. The opinions expressed in this Article are those of the author and do not necessarily represent those of the State Water Rights Board.

I See CAL. WATER Code $\$ \S 106.5,1006,1007,1203,1264,1460-64$. 
Under the old Cahifornia statutes ${ }^{2}$ no public officer had jurisdiction over appropriations of water. Every man was free to begin work incidental to the enterprise and after conipletion of the work to divert and beneficially use the water. Unasserted and unrecognized was the interest of the public in an orderly and comprehensive development of the water resources of the state through new appropriations of water in a manner which would insure that all water be put to the fullest beneficial use possible without impairing previously vested rights.

In 1911 the Legislature of California asserted the state's ownership of its natural water resources by aniending section 1410 of the Civil Code to read: ${ }^{3}$

All water or the use of water within the State of California is the property of the people of the State of California, but the right to the use of running water flowing in a river or streain or down a canyon or ravine unay be acquired by appropriation in the manner provided by law ....

In the same year the Legislature created the Conservation Commission.4 It was directed ${ }^{5}$

to prepare and recommend to the legislature, laws, statutes and constitutional amendments revising, systematizing, and reforming the laws of this State upon forestry, water, the use of water, water power, electricity, electrical and other power.

It prepared and submitted to the Legislature a draft of a "Water Commission Act" which, as revised and amended, was subsequently enacted. ${ }^{\circ}$

The major purpose of the Water Commission Act was fourfold: (1) to vest in the Commission broad powers to investigate and develop the facts concerning water sources; ${ }^{7}(2)$ to regulate the acquisition of rights to appropriate water ${ }^{8}(3)$ to provide a feasible method for the comprehensive determination of existing rights; ${ }^{9}$ and (4) to provide for distribution of water ${ }^{10}$ among those entitled to its use in accordance with the determined right of each user under state supervision. ${ }^{11}$

The act created a Water Commission composed of five members. ${ }^{12}$ Each commissioner was empowered to administer oaths and to issue sub-

${ }^{2}$ See CAx. Crv. Code $\$ \$ 1410-22$. These sections provided inter alia for posting and recording notice of appropriation, and made available to all who comphed therewith the benefits of the doctrine of relation. See note 46 infra.

3 Cal. Stats. 1911, c. 407, p. 821. See Cat. Water CODE $\$ 102$.

4 Cal. Stats. 1911, c. 408 , p. 822 .

5 Ibid.

${ }^{6}$ Cal. Stats. 1913, c. 586, p. 1012.

7 Id. \$§ 10, 40; Cal. Stats. 1925, c. 339, § 10a.

8 Cal. Stats. 1913, c. 586, \$§ 1-23.

9 Id. $\$$ 24-36.

10 More commonly known as "watermaster service."

11 Cal. Stats. 1913, c. 586, § 37.

12 Id. \$ 1 . 
poenas for the attendance of witnesses and the production of written documents and testimony in any inquiry, investigation, or hearing undertaken by the Commission. ${ }^{13}$ The Commission was authorized and empowered to investigate streams and stream systems or other bodies of water, to take testimony in regard to rights to use of water, and to ascertain whether such water, theretofore attempted to be appropriated, was appropriated under the laws of the state. ${ }^{14}$ Unappropriated water was defined to include all waters flowing in any stream, canyon, river, or other natural channel, excepting only so far as they are subject to riparian rights or otherwise appropriated; and further that such waters are public waters of the state and subject to appropriation in accordance with the provisions of the act. ${ }^{15} \mathrm{It}$ was also provided that stream waters subject to riparian rights, to the extent they were not put to beneficial use within ten years after the passage of the act, were to be conclusively presumed to be waste waters and should revert to the public and become water subject to appropriation under the act. $^{16}$

Section 15 provided that the Commission should allow, "under the provisions of the act, the appropriation of unappropriated water." Section 16 prescribed detailed information to be contained in an application for a permit to appropriate water. Section 17 provided that any person might apply for and secure from the Commission, in conformity with the act and with reasonable rules and regulations adopted by the Commission, a permit for unappropriated water, and that any application so made should give to the applicant a priority of right as of the date of its filing until the approval or rejection of the application by the Commission.

After approval of an application, construction of the work was required to be commenced and completed with due diligence in accordance with the act, the rules and regulations of the Commission, and the terms of the

$13 I d . \$ 4$.

14 Id. $\$ 10$.

15 Id. \$11.

10 Ibid. This portion of the Water Commission Act was held unconstitutional in Tulare Irrigation Dist. v. Lindsey-Strathmore Irrigation Dist., 3 Cal. 2d 489, 45 P.2d 972 (1935); see also Scott v. Fruit Growers Supply Co., 202 Cal. 47, 258 Pac. 1095 (1927). Also of particular interest are the concurring opinion of Shenk, J., in Fall River Irrigation Dist. v. Mt. Shasta Power Corp., 202 Cal. 56, 69, 259 Pac. 444, 451 (1927), and his dissent in Herminghaus v. Southern Cal. Edison Co., 200 Cal. 81, 123, 252 Pac. 607, 624 (1926).

Quaere: Since the ground for holding in the Tulare case was that by virtue of the 1928 amendment, adding CAI. CoNsT. art. XIV, $\S 3$, said $\S 11$ was unconstitutional, or was repealed by implication, what is the status of riparian rights not used for ten consecutive years between 1914 and 1928? Also Quaere: Is the holding of the Tulare case really dictum? See MEEse, ForFETTURE OF RIPARIAN RIGHTS FOR NON-USER (unpublished thesis in University of California, School of Law Library, Berkeley 1920); cf. Scurlock, Retroactive Legislation Affecting Interests in Land, in Mrcergar Legax Studies (1953). 
permit. Upon completion of use to the full extent contemplated, provision was made for verification of use of water made under the permit and issuance of a license accordingly. ${ }^{17}$ Failure to proceed with construction work and to complete it in conformity with the act, the rules and regulations, and the terms of the permit was made cause for revocation of the permit after notice and hearing, as well as ground for refusal to issue a license. Provision was made for an action in the superior court for review of such orders of the Commission. ${ }^{18}$ In the event the permittee or licensee should fail or cease to apply. the water to the useful or beneficial purpose for which the permit was granted, or should fail to observe any of the terms and conditions in the permit or license, the Commission, after notice and hearing, was empowered to revoke such permit or license. ${ }^{10}$

Two new procedures, designed to assist the courts in the determination of litigation involving rights to the use of water, were also included in the Water Commission Act as amended. ${ }^{20}$

It is to be noted that section 15 of the act required the Commission to allow appropriation of unappropriated water and that no discretion was given to the Commission to refuse an application. In 1917 section 15 was amended to read: ${ }^{21}$

The State Water Commission shall allow, under the provisions of this act, the appropriation for beneficial purposes of unappropriated water unless, in the opinion of the said Commission, such appropriation would be detrimental to the public welfare.

In 1921 section 15 was again amended to read: ${ }^{22}$

The State Water Commission shall allow, under the provisions of this act, the appropriation for beneficial purposes of unappropriated water under such terms and conditions as in the judgment of the commission will best develop, conserve and utilize in the public interest the water sought to be appropriated. It is hereby declared to be the established policy of this State that the use of water for domestic purposes is the highest use of water and that the next highest use is for irrigation. In acting upon applications to appropriate water the commission shall be guided by the above declaration

17 Cal. Stats. 1913 , c. $586, \S 37$.

18 Id. \$ 19.

${ }^{19}$ Id. $\$ 20$. See CAL. WATER Code division 1, and parts 1 and 2 of division 2 for codification of the Water Commission Act, as amended, constituting the existing law of state administration of rights to appropriate water. The foregoing parts of the code include all the regulatory and broad investigatory portions of the amended act.

20 Cal. Stats. 1917 , c. 153 , p. 231 ; Cal. Stats. 1931, c. 1135 , p. 2421 . In the original Water Commission Act of 1913 the court reference and statutory adjudication were alternate methods of initiating one procedure. Cal. Stats. 1913, c. 586, \$\$ 24-36. For a detailed description of these procedures see text beginning at note 90 infra.

21 Cal. Stats. 1917 , c. 133, p. 194.

22 Cal. Stats. 1921, c. 329, p. 443. 
of policy. The commission shall reject an application when in its judgment the proposed appropriation would not best conserve the public interest.

In 1919 the Water Commission Act was amended to provide that the executive member of the Commission should consider and act upon all applications for permits to appropriate water, and it was provided that an appeal might be taken to the Commission from any order of the executive member granting or refusing to grant a permit or a license, and the Commission was then required to review the proceedings, take such additional evidence as it deemed proper, and enter its order affirming, reversing, or modifying the order of the executive member. ${ }^{23}$

In 1921 a Department of Public Works was created by adding sections 363 through $363 \mathrm{~h}$ to the Political Code. ${ }^{24}$ By section $363 \mathrm{e}$ the Department succeeded to the duties, powers, and jurisdiction of the State Water Commission.

From 1927 to 1956 these powers were exercised by the State Engineer as Chief of the Division of Water Resources, Department of Public Works.

After two unsuccessful attempts in $1953^{25}$ and $1955^{26}$ the Legislature in 1956 adopted an act for the reorganization of certain of the agencies admimimstering the water laws of the state. ${ }^{27}$ The status and jurisdiction of many agenciès were altered little or none by the act. ${ }^{28}$ The Division of Water Resources of the Department of Public Works, the office of State Engineer, and the Water Project Authority were abolished. ${ }^{29}$ With certain exceptions, those functions of the Division of Water Resources which were derived from the Water Commission Act as amended (water right administration) were transferred to the State Water Rights Board..$^{30}$ All other functions of the Division were transferred to the Department of Water Resources headed by a Director appointed by the Governor subject to confirmation by the Senate. ${ }^{31}$

The Department of Water Resources succeeds to the functions of the Water Project Authority (construction and operation of state water projects such as the Feather River Project) and virtually all of those of the

23 Cal. Stats. 1919, c. 546, p. 1193 . "During the effective period of this procedure (two years) the record is not clear but there were either not many appeals taken, or none at all." Address by Henry Holsinger, Chairman, State Water Rights Board, Irrigation Districts Association of California Meeting, December 14, 1956.

24 Cal. Stats. 1921, c. 607, p. 1039.

25 S.B. 1657, A.B. 863.

26 S.B. 1655, 1659, 1885 ; A.B. 777.

27 Cal. Stats, 1956, 1st Ex. Sess., c. 52, \$1.

28 E.g., Reclamation Board, State and Regional Water Pollution Control Boards, Colorado River Board.

20 CaI. WATER CODE $\$ 154$.

80 Id. $\$ 189$.

31 Id. $\$$ 150, 153. 
State Water Resources Board (such as planning, allocation of flood control funds), which board is continued in existence in an advisory capacity as the State Water Board. ${ }^{32}$ The Department of Water Resources also succeeds to the powers of the Department of Finance relating to filing applications to appropriate water required in the development of coordinated state water planning. ${ }^{33}$

The State Water Rights Board is composed of three members appointed by the Governor, subject to confirmation by the Senate, for staggered fouryear terms; one member must be an attorney and one a registered civil engineer. ${ }^{34}$ The Department of Water Resources is declared to be an interested party in all hearings before the Board and in court actions involving the validity of decisions of the Board. ${ }^{35}$ The Attorney General represents the Board in litigation affecting the affairs of the Board unless the Department is a party to the action, in which event the Board is represented by staff counsel..$^{36}$

The work of the State Water Rights Board and its predecessors in water riglits administration has been and is for sometime anticipated to be in major part concentrated upon the administration of the law regulating appropriation of water. The Board lias inherited a heavy accumulation of pending applications to appropriate unappropriated water which will necessarily occupy the Board and its staff for an extensive period of time in reduction to reasonable proportions. ${ }^{87}$

II

\section{THE ADMTNISTRATIVE PROCESS}

We turn now to an analysis of those phases of the law of water rights in California which involve administrative law and procedure: (1) administration of rights to appropriate water, and (2) court references and statutory adjudications.

\section{A. Administration of Rights to Appropriate Water}

Administration of rights to appropriate water is the subject of part 2, division 2, of the Water Code. ${ }^{38}$ The regulatory authority conferred therein

32 Cal. Water Code $\$ \S 153,154$.

33 Id. \$153.

34 Id. $\$ \S 185,187$.

35 Id. $\$ 194$.

${ }^{36} I d$. $\$ 196$. The act further provides that the Board shall maintain its office at Sacramento and that all its meetings and hearings shall be open to the public. Id. $\$ 191$. "The Board interprets its organic act as requiring a physical separation of its office from that of the Department of Water Resources. Accordingly, as soon as was feasible, that separation was accomplished." Address by Henry Holsinger, Chairman, State Water Rights Board, Irrigation Districts Association of California Meeting, December 14, 1956.

37 "These ... include 22 applicants holding 66 applications; 73 individuals or entities have filed protests against one or more applications. The total number of protests which must be considered by the Board is $2,040 . "$ 1bid.

38 Car. Water CODE $\$ \$ 1200-1801$. 
extends only to surface streams, lakes, and other bodies of surface water, and to subterranean streams flowing in known and definite channels. Rights to the use of percolating ground water are not included in the regulatory scheme..$^{40}$ Riparian rights and appropriative rights acquired prior to December 19, 1914, are likewise exempted from regulation. ${ }^{11}$ Except as to those rights specifically exempted, the code method of appropriation is exclusive. ${ }^{42}$

There are three basic procedural steps in the acquisition of a right to the use of water by appropriation. They may be described as application, ${ }^{48}$ permit, ${ }^{44}$ and license. ${ }^{45}$ The first step is the filing with the State Water Rights Board of an application, together with the required fee, to appropriate unappropriated water. This is analogous to the posting and recording of notice under the former so-called code method of appropriation ${ }^{46}$ in effect prior to the enactment of the Water Commission Act. By filing the application the applicant secures a right of procedural priority, a conditional right to the future acquisition of a right to the use of water. ${ }^{47}$ The objective is to acquire a priority by publicly declared intent.

The second step comprises issuance of the permit which carries forward the right of procedural priority and adds the consent of the state to begin construction and to initiate the use of water, himited by the terms of the permit. There is no direct analogy to this step in the former code method.

The third step consists of issuance of the license. Issuance of the license does not create the right but is merely confirmatory of a right acquired by use in accordance with the permit. There is no analogy at all to this step in the former code method. Under the Water Code the right is acquired by use and lost by disuse, precisely the same as it was under the former code method, the essential difference being that under the Water Code acquisition of the right and its contmued existence is subjected to state supervision and, in instances, discretionary action to require conformity with the public interest.

39 Id. $\$ 1200$. See also id. \$1201.

10 Such waters are excluded by the definition of water subject to appropriation contained in Cal. Water Code $\$ 1200$. See also Code Commissioners' notes to Cas. Water Code $\$ 1200$. West, Cax. Water Code ANn. \$ 1200.

41 Cat. Water Code $\$ 1202$ (b).

$12 I d$. $\$ 1225$.

43 Id. $\$ \$ 1250-12 \nmid 1$.

44 Id. $\$ \$ 1375-1415$.

45 Id. \$ 1600-1677.

48 CAL. CTV. CODE $\$ 1415$. The code method of appropriation was implicitly repealed by the Water Commission Act, Cal. Stats. 1913, c. 586, p. 1012.

17 CaL. Water Code $\$ \$ 1450-1480$. 


\section{Procedure on Applications, Permits, and Licenses}

Any person may file an application for a permit to use unappropriated water. ${ }^{48}$ The contents of the application are specified; ${ }^{49}$ forms are provided by the State Water Rights Board; opportunity is afforded to correct defective applications; $;^{50}$ the application is noticed either by posting and mailing $^{51}$ or publication; ${ }^{52}$ any person interested may file a protest to the application within the time allowed by the notice. ${ }^{53}$ By administrative regulation answers to valid protests are required of applicants. ${ }^{54}$

On all protested applications, hearings are required. ${ }^{55}$ An unprotested application nuay be granted, but not rejected, without a hearing. ${ }^{50}$ Technical rules of evidence need not be applied in the conduct of hearnigs. ${ }^{67}$ As prerequisite to issuance of a permit, the applicant nust pay all fees due and establish that the proposed use is beneficial and that unappropriated water is available to the applicant. ${ }^{58}$ In addition the Board is required to reject an application when in its judgment the proposed application would not best conserve the public interest. ${ }^{50}$ The Board is also authorized to allow the appropriation under such terms and conditions as in its judgment will best develop, conserve, and utilize in the public interest the water sought to be appropriated. ${ }^{60}$ The effect of this discretionary power is that the Board may, if the facts justify such action, grant the application subject to terms and conditions requiring the applicant to conform to requirements of the

\footnotetext{
48 CAL. WATER CODE $\$ 1252$.

49 Id. $\$ 1260$.

50 Id. $\$ 1270$.

51 Id. $\$ \S 1320-1323$ (minor diversions).

52 Id. $\$ \$ 1310-1316$ (major diversions).

63 Id. § 1330.

5423 Cax. Admen. Code $\$ \S 723,724$. See also State Water Rights Board Resolution No. 4, adopted October 1, 1956.

${ }^{65}$ CAI. WATER Code $\$ \$ 1340-1353$. In practice the Board and its predecessors have, by stipulation of the agency and all interested parties, pursuant to regulation (23 CAL. ADMrs. CODE $§ 737$ ), dispensed with hearings on contested applications in a majority of cases involving minor quantities of water. The policy has heen to hold hearings on all major contested applications and any others where the public interest appears to be a significant factor. These proceedings "in lieu of hearing". have resulted im a great saving of time and expense to the partics and the state. The stipulations specify the nature of the records and information upon which the decisions will be based. Advance notice of any field investigation must be given to all parties, and the Board must indicate in its decision all of the records, documents, and data constituting the transcript of evidence in case further proceedings inight arise. Copies of the transcript may be obtained at cost. Results of these "in lieu of hearing" proceedings, including the public reaction, indicate their success.

5o CAT. WATER CODE $\$ 1351$.

57 Id. \$1353:

58 Id. $\$ 1375$.

59 Id. $\$ 1255$.

60 Id. § 1253 .
} 
public interest. ${ }^{61}$ Hearings are conducted by the Board or by a member upon authorization of the Board. ${ }^{62}$

Upon issuance of the permit, construction work is required to begin not less than 60 days from date of the permit, ${ }^{63}$ and the work must be completed and the water applied to beneficial use within the time specified therein; ${ }^{64}$ however, extensions of time may be granted for good cause shown. ${ }^{65}$ Failure to commence or complete the project within the allowed time is ground for revocation of the permit. ${ }^{68}$ Such revocation can be made only after hearing. ${ }^{67}$

Upon proof of completion of the works and application of the water to beneficial use in conformity to law and the terms of the permit, a license must be issued to the permittee. ${ }^{68}$ If the permittee has not complied with the applicable law, after hearing the license may be denied. ${ }^{68}$ Provision is made for revocation of licenses after notice and hearing. ${ }^{70}$ Copies of licenses ${ }^{71}$ and final orders of revocation ${ }^{72}$ are filed by the Board in the office of the recorder of the county or counties in which the point of diversion and place of use lie.

The Code also makes provision for permission to change the point of diversion, place of use, or purpose of use, under permit or license, where such change will not operate to the injury of any legal user of water..$^{73}$

The Administrative Procedure Act ${ }^{74}$ is not applicable to the State Water Rights Board. ${ }^{75}$ Some of the provisions of that act represent a codification of basic principles of procedural due process of law. As to the latter, it is the practice of the Board in all water right hearings to conform thereto as closely as possible. ${ }^{76}$

61 East Bay Municipal Util. Dist. v. Department of Public Works, 1 Cal. 2d 476, 35 P.2d 1027 (1934).

62 CaL. WATER Code $\S 193$.

Q3 Id. $\$ 1395$.

64 Id. $\$ 1397$.

65 Id. § 1398.

66 Id. $\$ 1410$.

67 Id. \$ 1410-1415.

68 Id. $\S 1610$. The mandatory nature of $\S 1610$ is considerably weakened by the fact that the Board makes a discretionary determination as to completion.

69 Id. § 1611.

70 Id. $\$ 1675$.

71 Id. $\$ 1650$.

72 Id. \& 1651 .

73 Id. \$\$ 1700-1706.

74 Car. Govr. Code $\$ \S 11500-11528$.

75 The Administrative Procedure Act is applicable only to those agencies whose enabling statute so states or who are listed in CAr. Govr. CoDE § 11501.

76 E.g., if any public records are to be considered by the Board, the procedure prescribed by CAr. Govr. CODE $\S 11515$ is followed. "The practice [has been] adopted that in advance of hearing of an application, or combined hearing of a nunber of applications, a staff report is formulated and copies are served on all parties who have appeared, which contains among other 
An interesting problem not governed by any provision of the Code involves extensions of time to commence or complete work under a permit. No permit may be revoked without a hearing, ${ }^{77}$ but no hearing is required upon a request for extension of time. ${ }^{78}$ Since revocation proceedings can be instituted only by the Board, ${ }^{79}$ no administrative remedy is spelled out whereby a party adversely affected by extensions of time can assert his rights. Procedural due process would appear to require the Board to determine the facts by holding a hearing prior to granting an extension of time when demanded by the party asserting such adverse interest. ${ }^{80}$

\section{Judicial Review}

In 1921 the California Supreme Court in Tulare Water Co. v. State Water Comm'n ${ }^{81}$ held that under then existing statutes issuance of a permit to appropriate water pursuant to an application in proper form was a ministerial duty which would be compelled by writ of mandate. The Water Commission Act in its original form was declared to grant a positive right to such permit to any person making a proper application. In 1923 section 1(b) was added to the Water Commission Act, ${ }^{82}$ establishing a method of review of an order of the State Water Commission issuing or refusing to issue a permit, by bringing an action in the superior court. Although section 1(b) was held to be unconstitutional in $1927,{ }^{83}$ it was subsequently re-enacted ${ }^{84}$ without substantial change and now comprises sections 1360 through 1363 of the Water Code. ${ }^{85}$

matters a list of exhibits comprising official documents containing information relevant to the hearing, and notice is given in the report that these exhibits will be officially noticed or offered in evidence at the hearing by reference. By this uneans the parties are apprised of a ficld of information which the Board considers proper to consider at the hearing and if any party has objection thereto he will have an opportunity to register the objection. If no objection is advanced, then the parties will be cognizant that there will be no need for them to introduce evidence to establish such facts, and thereby the hearing will be shortened and a substantial saving will be made in time and expense. It is beheved the practice has a salutary effect and has facilitated arriving at just results with a minimum of time and expense." Address by Henry Holsinger, Chairman, State Water Rights Board, Irrigation Districts Association of California Meeting, December 14, 1956.

77 CAL. WATER CODE $\$ 1410$.

$78 I d . \S 1398$.

79 See note 77 sicpra.

80 " $\mathrm{It}$ is the policy of the State Water Rights Board, notwithstanding anything to the contrary or in apparent conflict herewith in this resolution contained, that when an extension of time is involved which concerns a coinparatively extensive development or otherwise important project, that the required showing on the part of the party requesting the extension, shall be made by a personal appearance before the Board in meeting assembled." State Rights Board Resolution No. 3, adopted October 1, 1956.

81187 Cal. 533, 202 Pac. 874 (1921).

82 Cal. Stats, 1923 , c. $86, \S 2$.

83 Mojave River Irrigation Dist. v. Superior Court, 202 Cal. 717, 262 Pac. 724 (1927).

84 Cal. Stats. 1939 , c. $838, \$ 2$.

85 But see Temescal Water Co. v. Department of Public Works, 44 Cal. 2d 90, 280 P.2d I (1955). 
The supreme court has declared several times that in exercising its statutory jurisdiction with respect to appropriations of water, the agency does not act judicially, since the Legislature cannot under the constitution give judicial power to any general state board or tribunal. ${ }^{86}$ Therefore, certiorari will not lie to review a decision of the agency. ${ }^{87}$

In Temescal Water Co. v. Department of Public Works ${ }^{88}$ it was determined that statutory changes have created a type of proceeding greatly different from that considered in the Tulare case, and that in carrying out its present duty, the State Water Rights Board exercises a broad discretion in determining whether issuance of a permit will best serve the public interest; therefore, the proper remedy for reviewing the issuance of a permit protested upon the grounds of unavailability of unappropriated water is by a writ of mandate pursuant to section 1094.5 of the Code of Civil Procedure. The Temescal case held that in order to state grounds for review, the petition for writ of mandate must allege petitioner's participation in the administrative proceedings upon the application in accordance with the familiar rule that administrative remedies must be exhausted before the courts will act. ${ }^{80}$

\section{B. Court References and Statutory Adjudications}

In addition to establishing administrative control over rights to the use of water by appropriation, the Water Commission Act as amended introduced two new procedures in California law involving court adjudications of water rights. These are the court reference procedure ${ }^{90}$ and the statutory adjudication..$^{91}$ Both procedures are designed to minimize the expense and delay of water rights litigation.

The court reference procedure is based upon the long established practice of equity courts of appointing a master to nake the initial determination of all or part of the controversy before the court. In any suit for determination of rights to water the court may order a reference to the State Water Rights Board, as referee, of any or all issues involved in the suit ${ }^{22}$ or of any or all of the physical facts involved..$^{93}$ The order of reference may be made at any time after filing the complaint. ${ }^{94}$ Issues may be joined before or after the order of reference, and if after, an automatic transfer

80 See note 81 supra.

87 Department of Public Works v. Superior Court, 197 Cal. 215, 239 Pac. 1076 (1925).

8844 Cal. 2d 90, 280 P.2d 1 (1955):

89 Id. at 106,290 P.2d at 11.

90 CAL. WATER CODE $\$ \$ 2000-2076$.

91 Id. $\$ \$ 2500-2900$.

92 Id. $\$ 2000$.

93 Id. \$2001. It has been the practice of the agency to recommend that all references be made pursuant to section 2001 only, i.e., to find the facts and report thereon to the court.

94 Fleming v. Bennett, 18 Cal. 2d 518, 116 P.2d 142 (1941). 
to the referee of such issues as have been referred by the order would occur. ${ }^{95}$ As the order is in no way dependent upon consent of the parties, it appears that there is no sound objection to this procedure, and the order may be considered the formal appointment and statement of powers and duties of the referee.

The Board may base its report upon its own investigations or upon hearings and testimony taken. ${ }^{96}$ These powers exceed those of an ordinary referee since under a code reference ${ }^{97}$ a referee is required to base his findings upon evidence regularly admitted at hearings. ${ }^{98}$ However, there does not appear to be any well grounded objection to the procedure as it is common practice for trial courts in water suits to make personal examination of the premises-denominated "a view" - and to use information so acquired in its findings and decree. ${ }^{99}$ Further, this investigational work of the referee may be compared to the activities of an expert witness appointed by the court and directed to submit his evidence in writing. ${ }^{100}$

The report of the referee may contain such opinion upon the law and facts as it may deem proper in view of the issues submitted, ${ }^{101}$ and the findings are prima facie evidence of the physical facts found in the report. ${ }^{102}$

Before the report is filed with the court, ${ }^{103}$ a draft is served by mail on the parties. ${ }^{104}$ Objections may be filed with the Board within thirty days after service. ${ }^{105}$ After consideration of such objections, with a hearing thereon if deemed advisable, the Board files its report with the court and gives notice thereof to the parties by mail..$^{108}$

Exceptions to the report may be filed with the court within thirty days after notice of filing the report. ${ }^{107}$ Exceptions are limited to matters presented to the referee by way of objection except in the court's discretion for good cause shown. ${ }^{108}$ The report is subject to review by the court upon the exceptions ${ }^{109}$ and testimony introduced in support thereof by any party. ${ }^{110}$

The actual expenses incurred by the Board as referee are chargeable as costs. ${ }^{111}$ The total expense is equitably apportioned by the Board against

\footnotetext{
95 Automatic transfer is by necessary implication from CAL. WatzR CODE $\$ 2021$. See also Fleming v. Bennett, supra note 94.

96 Cal. Water Code $\$ 2010$.

97 See Caz. Code Crv. Proc. $\$ \S 638,639$.

98 It re McNamee, 131 Cal. App. 30, 20 P.2d 722 (1933).

99 KINNEY, IrRTGation AND WATER Rights 2800 (2d ed. 1912).

100 Fleming v. Bennett, 18 Cal. 2d 518, 116 P.2d 422 (1941).

101 CaL. WATER CODE $\$ \S 2011,2012$.

102 Id. § 2019.

103 See id. § 2013.

104 Id. $\S 2014$.

108 Id. $\$ 2018$.

105 Id. $\$ 2015$.

109 Id. \& 2017.

106 Id. \$ 2016.

110 Id. \& 2019.

107 Id. \$ 2017.

111 Id. \$ 2040 .
} 
the parties, and a statement of the expenses and apportionment is mailed to the parties and filed with the court. ${ }^{112}$ Objections and exceptions to the expenses and apportionment may be made as in the case of the report itself. 113

Decrees have been entered in twenty-mine court reference proceedings; eleven proceedings are now pending. The costs of reference have been relatively low in comparison to similar cases in which there has been no reference. Where irrigation rights have been involved, costs have been in the main less than $\$ 2.00$ per acre irrigated. One of the reasons for relatively low costs has been the records and information readily available to the referee relative to the facts involved in the references.

Appeals have been taken in two court reference proceedings. ${ }^{114}$ In both cases the constitutionality of the procedure was upheld and the trial court's decision based upon the referee's report was affirmed.

The statutory adjudication procedure provides for the determination of all rights to water of a stream system whether based upon appropriation, riparian right, or other basis of right. ${ }^{115}$ Rights to an underground water supply other than a subterranean stream flowing through known and definite channels are excluded. ${ }^{116}$ Thus, rights to percolating ground water may be adjudicated in a court reference proceeding but not in a statutory adjudication.

Upon petition by one or more claimants to the use of water of a stream system requesting a determination of the rights of the various claimants, the State Water Rights Board is required, if it finds that the public interest and necessity will be served by such a determination, to enter an order granting the petition and to arrange for further proceedimgs. ${ }^{117}$ As soon as practicable after granting the petition, the Board prepares and publishes a notice of the entry of the order, the pendency of the proceeding, and the date when the Board will begin its examination; it also requires that all claimants make proof of their claims as provided in the act. ${ }^{118}$ Then follows a detailed investigation by the Board of the stream system, conduits, lands irrigated, and all other items essential to proper determination of the water rights involved. ${ }^{119}$

After completion of the investigation the Board prepares a notice of the due date for filing proofs $\mathrm{s}^{120}$ and publishes ${ }^{121}$ and mails ${ }^{122}$ it by registered

112 Id. $\$ 2043$.

113 Id. $\$ \S 2045,2046,2048$.

114 City of Pasadena v. City of Alhambra, 33 Cal. 2d 908, 207 P.2d 17 (1949) (surface stream); Fleming v. Bennett, 18 Cal. 2d 518, 116 P.2d 442 (1941) (ground water).

115 CaI. Water CODE $\$ 2501$.

$116 I d$. § 2500 .

$120 \mathrm{Id} . \S 2575$.

117 Id. $\$ 2525$.

121 Id. $\$ 2577$.

118 Id. \& 2526.

122 Id. $\$ 2578$.

119 Id. § 2550; see also id. $\S \S 2551-54$. 
mail to each known claimant, enclosing forms of proof. ${ }^{123}$ Upon these forms are required to be submitted the details upon which each claimant bases his claim of right, ${ }^{124}$ certified under oath. ${ }^{125}$ Upon failure of any claimant to file his proof the Board is required to determine his right upon the basis of such evidence as it may obtain or have available. ${ }^{126}$ After the date for filing proofs has expired the Board prepares an abstract of proofs ${ }^{\mathbf{1 2 7}}$ and mails each claimant a copy of the abstract and a notice of the period when and the place where the proofs will be available for inspection by all interested persons. ${ }^{128}$

After the period of inspection of proofs, provision is made for contest of proofs by filing notice of contest. ${ }^{129} \mathrm{~A}$ hearing is then held-after notice -and evidence is taken for and against the contested claims of right. ${ }^{180} \mathrm{~A}$ transcript of the hearing is prepared and the cost is charged to the parties. ${ }^{181}$ Following the hearing, the Board prepares an order determining the several rights, each against all others, to the water of the stream system. ${ }^{132}$ Copies are mailed to all parties, ${ }^{133}$ and a certified copy together with the original evidence and transcript of testimony are filed with the clerk of the superior court of the county in which the stream system, or portion thereof, is located. ${ }^{134}$

The right of intervention is given to all claimants who have received no actual notice of the proceedings, providing they file a petition to intervene with the Board at any time before three months after entry of the order of determination. ${ }^{135}$ There is also provision for reopening of the proceedings and granting a rehearing by the Board for good cause shown within a period of thirty days after entry of the order of determination. ${ }^{186}$

A court order setting a time for hearing is then procured by the Board ${ }^{187}$ and copies thereof are mailed to each party, ${ }^{138}$ who may then file with the court notice of exceptions to the board's order of determination. ${ }^{139}$ The order of deterinination, the statements (proofs) of claimants, and the exceptions to the order constitute the pleadings ${ }^{140}$ although the court may, if it finds necessity therefor, allow further pleadings. ${ }^{141}$ In the absence of exception, on motion of the Board the court is required to enter a decree affirming the order of determination. ${ }^{142}$ When exceptions are filed, the

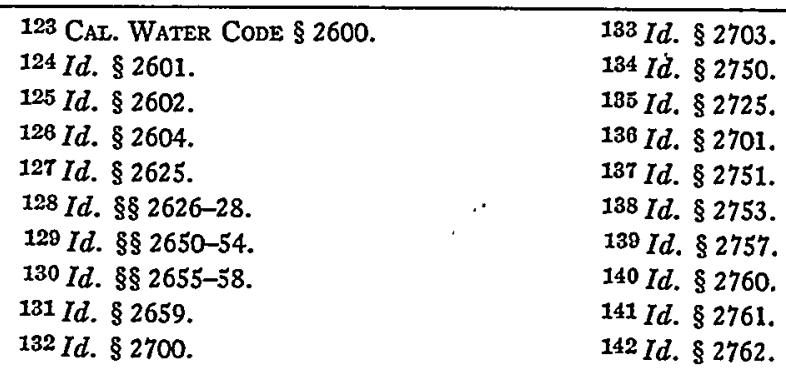


issues are determined at the hearing, ${ }^{143}$ which is conducted as nearly as may be in accordance with the rules governing civil actions. ${ }^{144}$ If in the court's judgment the state is a necessary party, an order is entered to that effect and copies of all pleadings and proceedings on file are served on the Attorney General. ${ }^{145}$

The court may employ experts to investigate and report under oath, subject to examination by any party as to their competency as experts. ${ }^{148}$ The court may require additional evidence to be taken by the Board or may direct a further determination by it. ${ }^{147}$

After hearing the court is required to enter a decree determining the rights of all parties, ${ }^{148}$ declaring the extent, priority, amount, season of use, purpose of use, point of diversion, and place of use including specific tracts of lands to which irrigation rights are appurtenant, and any other factors necessary to define each right as against every other right involved. ${ }^{149} \mathrm{~A}$ copy of the decree is filed by the clerk of the court with the recorder of each county in which any part of the stream system is located, and also in the office of the Board. ${ }^{150}$ The decree is in rem, ${ }^{151}$ and failure to appear and submit proof of claim results in a forfeiture of right, other than as provided in the decree. ${ }^{152}$

The Board is authorized in its order of determination to fix the time for completion of incomplete appropriative claims which have been initiated according to law and prosecuted with reasonable diligence. ${ }^{153}$ Jurisdiction over such incomplete rights thereupon vests in the court. ${ }^{154}$ Time for completion may be extended by the court after hearing on motion of claimant for good cause shown. ${ }^{155}$ Upon proof of completion and hearing thereon, if made after entry of the decree, a supplemental decree is entered adjudicating the right. ${ }^{158}$

It is provided that in both court references and statutory adjudications the court may retain jurisdiction to modify the decree upon application of any party or by the State Water Rights Board within three years after entry, but only in so far as the decree determines quantities of water. ${ }^{157}$ A broader but still limited retention of jurisdiction was rejected, and a retained jurisdiction of reasonably broad scope was approved, without mention of Water Code section 2900, in City of Pasadena v. City of Alhambra. ${ }^{153}$

Thirteen statutory adjudication proceedings have been completed. Two

$143 I d . \S 2763$.

$144 I d . \$ 2764$.

145 Id. $\$ 2765$.

$146 \mathrm{Id}$. $\$ 2766$.

147 Id. $\$ 2767$.

148 Id. § 2768.

$149 \mathrm{Id}$. $\$ 2769$.

150 Id. $\$ 2772$.
151 Id. \$ 2773.

152 Id. § 2774.

153 Id. $\$ 2800$.

154 Td. § 2805.

155 Id. \& 2807.

$156 \mathrm{Id}$. § 2815.

157 Id. $\$ 2900$.

15833 Cal. 2d 908, 207 P.2d 17 (1949). 
such adjudications are presently pending. No appeal has been taken from an adjudication decree. However, in Wood v. Pendola ${ }^{159}$ and Bray v. Superior Court ${ }^{160}$ the constitutionality of the procedure was upheld against collateral attack.

III

\section{EFFECTS OF THE ADMINISTRATIVE PROCESS UPON IITIGATION}

For two or three decades prior to the enactment of the Water Commission Act there were, on the average, between seven and eight cases involving the determination of water rights decided annually by the appellate courts in Califorma. This average continued for several years after the date of the act and then gradually declined. Since 1935 the average has been only a fraction over three cases reported per year. Since total litigation has increased greatly over this period, and the pressure on existing water supplies likewise has increased, it is believed reasonable to generalize that the administrative procedures established by the Water Commission Act, as amended, have tended to reduce litigation over water rights. The Board and its predecessors have received more than 17,000 applications to appropriate water and have issued more than 10,000 permits and 4,300 licenses. Approximately 700 licenses and 2,900 permits have been revoked. More than 850 formal decisions have been rendered. In only eight reported cases, however, has the administrative determination been attacked by court proceedings. ${ }^{161}$

In addition, it is believed that the decrees entered in the statutory adjudications and court reference proceedings have been more satisfactory and were obtamed at lower cost than in traditional water right litigation and that the burden of the trial courts has been materially lessened. ${ }^{102}$ This was emphasized by the supreme court in Fleming v. Bennett: ${ }^{103}$

- The report appears to be definite, comprehensive, and an expeditious solution of the numerous rights to the use of waters in this extensive area. As indicated by the cases hereinbefore cited, this court has heretofore commended and approved the prescribed plan for expediting the determination

1501 Cal. 2d 435, 35 P.2d 526 (1934).

16092 Cal. App. 428, 268 Pac. 374 (1928).

161 Temescal Water Co. v. Department of Public Works, 44 Cal. 2d 90, 280 P.2d 1 (1955); East Bay Municipal Util. Dist. v. Department of Public Works, 1 Cal. 2d 476, 35 P.2d 1027 (1934) ; Mojave Irrigation Dist. v. Superior Court, 202 Cal. 717, 262 Pac. 724 (1927) ; Department of Public Works v. Superior Court, 197 Cal. 795, 239 Pac. 1080 (1925); Tulare Water Co. v. State Water Comm'n, 187 Cal. 533, 202 Pac. 874 (1921) ; Ricl v. McClure, 78 Cal. App. 209, 248 Pac. 275 (1926) ; Santa Ana Valley Irrigation Co. v. Schnack, filed Feb. 1955, Superior Court of Riverside County No. 61146; Tule Irrigation Dist. v. Purcell, filed Sept. 1948, Superior Court of Sacramento County No. 79613.

162 See Meridian, Ltd. v. San Francisco, 13 Cal. 2d 424, 457, 90 P.2d 537, 553 (1939).

16318 Cal. 2d 518, 527, 116 P.2d 442, 447 (1941). 
of conflicting water rights in this state by reference to the Division of Water Resources. Counsel representing defendants owning or controlling more than one lialf of the area affected has pointed out the disadvantages and excessive cost of piecemeal litigation on the Susan river for over fifty years and the satisfaction generally felt in having a comprehensive solution of all of the water rights on the stream in this one proceeding. Here all of the material issues and the rights of all the users in the watershed were settled by the facts found by the court based on the report of the referee and additional evidence which necessitated only a short hearing. ...

The efficiency of the administrative process appears to be well established.

IV

\section{THE ADVENT OF MASTER WATER PLANNING}

A new and highly significant element is entering the scene of water development and water rights in California. The Legislature, by the State Water Resources Act of 1945 , as amended, ${ }^{164}$ and by annual appropriations commencing in 1947, authorized and directed the State Water Resources Board ${ }^{165}$ to prepare and submit to the Legislature a long-range plan for the development, control, and conservation of all the state's water resources, both surface and underground, in order to meet the present and foreseeable future needs for water in all areas of the state. ${ }^{166}$ The plan, to be entitled "The California Water Plan," is under preparation by the Director of Water Resources and his staff; both a preview and a preliminary edition thereof have recently been published. ${ }^{167}$ Included in the tentative plan are at least 260 new major reservoirs with storage capacity of 60 million acre feet, ${ }^{168}$ hydroelectric installations of about three times the present installed capacity, extensive aqueducts and pumping systems, and regulated storage in ground-water basins. The plan is designed to meet the estimated total consumptive requirements of the state of $51,000,000$ acre feet, or about two and one-half times the present total usage.

The California Water Plan does not contemplate that all units will necessarily be constructed and operated by the state. Many of the smaller units could appropriately be built and operated by local agencies; nor is the plan designed to shut out private enterprise. However, the Legislature has already authorized state construction of the Feather River Umit, ${ }^{169}$ and

164 Cal. Stats. 1945 , c. 1514, p. 2827 , amended, Cal. Stats. 1951, c. 1230, p. 3076. These statutes are now codified in CAL. WATER CODE $\$ \$ 125 \% 0-875$.

165 Now the Department of Water Resources. CaL. WATER Code $\$ \S 153,154$.

106 Cf. CaL. WATER CODE $\$ 12616$.

107 State Water Resources Board, Preview of the California Water Plan (1956); State Water Resources Board, Bull. No. 3, Report on the California Water Plan, PreITMINARY EDITION (1956).

108 This amounts to three times the storage capacity of existing reservoirs.

109 CaL. Water Code $\$ 11260$, as amended by Cal. Stats. 1956, Ex. Sess., c. 54, $\S 1$. 
money has been appropriated for surveys, site acquisition, relocation of highways and public utilities. ${ }^{170}$

From the legal viewpoint one of the most significant elements of The California Water Plan is the provision for planned operation of groundwater basins on a scientific basis to provide cyclic storage for both local and imported waters. The recurrence of dry cycles and the economic limits of available surface storage capacity require regnlation of ground-water storage to meet the ultimate demands for firm water supplies. To effectuate such regulation legislation is necessary. ${ }^{171}$

The following suggestions for legislation, relating largely, although not exclusively, to water rights administration, cover a rather broad field of subjects. They do not purport in any way to cover the entire subject matter. Some of these proposals are not dependent upon the advent of statewide master water planning; however, the latter factor does give emphasis to most, if not all of the suggested changes. These suggested changes are:

1. Mandatory Recordation of Ground Water Extractions: In 1955 the Legislature provided for mandatory recordation of ground water extractions in five southern Cahfornia counties. ${ }^{172}$ This should be broadened to include the entire state. This is a first step in any adequate system of regulation and would materially assist in adjudications. ${ }^{173}$

2. More adequate control over construction and abandonment of water wells is needed for pollution prevention.

3. Court Reference and Statutory Adjudication Procedures: ${ }^{174}$

(a) A practical lis pendens procedure should be supplied. This should apply to both the court reference and the statutory adjudication procedure.

(b) The trial court should be authorized to refer any case involving the determination of water rights, surface or underground, at any time after filing of the complaint to the State Water Rights Board with direction to follow either the statutory adjudication procedure or the court reference procedure. This would supply a most desirable flexibility.

(c) The trial court should be authorized to impose, from time to time, trial distribution schedules. This also should apply to both procedures.

(d) All rights to the use of water, mcluding ground-water rights, should be included within the scope of the statutory adjudication procedure.

(e) Provision should be added to the statutory adjudication procedure

170 Cal. Stats. 1956, c. 1, items 419.5 and 419.6.

171 See Holsinger, Some Legal Aspects of Ground Water and the California Water Plan, 47 J. AM. WATER Works Ass's 374 (1955).

172 CaI. Water Code $\$ \S 4999-5008$.

173 The objective of recordation is to accumulate information which will enable protection of the water rights of the users and, in event of a comprehensive adjudication of common sources of supply, minimize the expense and delay of such adjudication.

174 For derivation of the succeeding recommendations see note 171 supra. 
to the effect that initiation of a proceeding tolls the statute of limitation and that an action to adjudicate the rights, in whole or in part, involved in any such proceedings, filed during the pendency thereof, on motion of the Board shall be abated.

(f) The trial court should be authorized to impose a physical solution, either as recommended by the referee or as suggested by the court or the parties, and to enter any other order as the interests of justice may require. This should apply to both procedures.

(g) The trial court should be given the definite power to control not only the amount of extraction but also the pattern thereof.

(h) In entering its judgment the trial court should retain broad jurisdiction in accordance with the principles approved by the Supreme Court of California. ${ }^{175}$ This also should apply to both procedures.

4. Comprehensive State Regulation of Ground Water Storage and Extraction: The foregoing suggestions are essentially niere extensions of and improvement in existing legislation. They represent inmediate steps that can be taken to improve existing law, to correct discrepancies and to assist in implementing The California Water Plan. Eventually to effectuate the ultimate plan, the following major statutory changes would appear necessary:

(a) Enactments authorizing (1) the planned utilization of groundwater basins for carry-over storage and (2) adjustment of conflicts with existing rights either by delivery of water or by cash compensation.

(b) The requirement of permits and licenses for the appropriation of ground water, authorizing extensive draw-down of ground water levels in time of need.

(c) Control and supervision of recharge of depleted ground-water basins.

\section{CONCLUSION}

A generation or so ago the subject of water rights was essentially a matter of private rights in which the parties took their disputes directly to the courts to resolve the controversies which arose. Gradually in California and throughout the West, where the economy depends on the efficient utilization of limited water resources, the subject has become more and more one of public concern. The private right has of necessity become restricted to a greater extent in the pubhic interest. The role of the pubhic agency, staffed by persons of specialized knowledge and experience, is becoming more and more important. The courts are still called upon to finally resolve

175 See City of Pasadena v. City of Alhambra, 33 Cal. 2d 908, 207 P.2d 17 (1949). 
disputes concerning rights to the use of water, but increasingly only on review of the action taken by a public official or body. It would appear that administrative law is firmly established in the field of water rights. ${ }^{176}$ 